\title{
The Effects of Task-Based Language Teaching (TBLT) on the Reading Comprehension in EFL Classes
}

\author{
Ozcan Demirel (Corresponding author) \\ ELT Department, Ankara University, Ankara, Turkey \& Cyprus \\ E-mail: demirel.ozcan@gmail.com
}

\begin{abstract}
Nadia Ben Amer
ELT Department, Cyprus of International University, Nicosia, Cyprus

E-mail: nadiabenamer120@gmail.com
\end{abstract}

Received: September 5, 2017 Accepted: October 12, 2017 Published: October 15, 2017

doi:10.5296/elr.v3i2.11976 URL: http://doi.org/10.5296/elr.v3i2.11976

\begin{abstract}
This study investigated the effects of Task-Based Language Teaching (TBLT) on the reading comprehension in EFL classes at proficiency Cyprus Universities. In addition, this study attempted to find out whether the Task-Based Language Teaching has any advantages or disadvantages in teaching reading skills to EFL learners. This study attempted to determine the effects of the Task-Based Language Teaching on the reading comprehension of foreign EFL learners. This study uses both quantitative and qualitative methods collected data from different two universities. The two different universities are Cyprus International University and Mediterranean Karpasia University.
\end{abstract}

Keywords: Task-Based Language Teaching, Reading skills, EFL proficiency level 1. Introduction

In English language teaching, the importance of an approach for students is really to acquire English capability and English acquisition. According to Allen, and Widdowson, (1974) stated that an approach is approach is axiomatic. It describes the nature of the subject matter to be taught. Approach is discussing about underpinning theory of language and the application of theory. Teachers have to make the classroom to be a place where the students can acquire the meaningful of communicative learning. Moreover, the students also have to involve themselves in teaching learning process based on which is the approach that the teachers use so they can develop their own skills in language learning. There are many approaches that can be 
used by the teachers in language teaching to make the students achieving their aims in language learning and how to use language for communication. For example, the approach that focuses on grammatical form or the approach that focuses on the task which is given by the teachers to the students. This proposal will describe the effectiveness of both task-based approach and content-based approach in language teaching reading skill at EFL.

Task-based instruction is given by the teacher to students who is in favor of learner involvement. This task is sharing by both the students and the teacher. Teacher encourage students by asking them some questions. They attend the courses actively. Students complete the given task which provides a peer-learning. Teacher teach students how to implement a task by working in a group in the class. This is called pre-task stage. Pre-task stage helps the students to do the next task correctly. It prepares them for the next task which they will work individually or in a group. After they completed a task, they are expected to manage the rest of the task with their groups. Students share their discussion and ideas about the task. A gap activity also emerges. They also evaluate their task by themselves that make them feeling confidence, and provide a peer-evaluation. The activity which the students complete the rest of the task after learning the ways. It is called ongoing -task. After the while task, the students are expected to do a new task working in groups. The subject of the task will be different from the completed one. Students will practice with their acquaintances on the new task. They share their share their ideas. At the end, they will produce something on their own. This is called post-task. The students attempt to complete post-task, they interact and do an opinion-gap activity between students. The task-based activity develops students' language skills. They improve their target language. Task-based approach and content-based approach have the aim to increase students' English acquisition. The both of two approaches enable an instrument to increase stu dents' capabilities in English. These approaches will develop and promote students' language skills and critical thinking in English learning. The function of both approaches in language teaching that is to make real communication in the classroom between students and teachers or between students in group activity. Task-based approach and content-based approach have a role that is to teach students their needs in language. All the students desire to develop their capabilities in learning English as a Second Language (ESL) or English as a Foreign Language (EFL). The target is being centered in teaching learning process. The teachers are giving the materials and tasks to the students. Furthermore, the students learn the material and carry out the tasks in teaching learning process based on their own capabilities. They can develop the tasks with their own skills and teachers only assess the outcome what they have carried out.

Task-based approach focuses on communicative and cognitive processes. The students are able to develop their language skills naturally by communicate with others about the task that they carry out. On the other side, content-based approach concerns with information that focus on the fact of content and understanding of information. Students achieve their target based on the academic subject in order to develop their language skills. It is clear that both of these two approaches have the same goal in language teaching. These approaches improve students' capability and acquiring English language. Teachers should choose which appropriate approach for students that based on their needs and students are be able to communicate accuracy and fluency (Bowen, 2004). 


\subsection{Purpose of the Study}

The purpose of this study is to investigate whether teaching reading through Task-Based Language Teaching (TBLT) has any effect on the reading comprehension of foreign proficiency learners. In addition, the present study will investigate to see if there is any significant difference or similarities between methods used in teaching reading to the foreign learners. Also this study attempts to find out whether task-based approach has any advantages in teaching reading skill to EFL learners.

\subsection{Significance of the Study}

This study concerned reading comprehension that is important for learners and proficiency learners. Learners needed to understand when they read texts in different field. This study will investigate how foreign learners understand texts in English language courses. Also how methods and approaches have been used in the class? Is there any effectiveness? The main core in this study is to investigate if task-based can be effected to the reading comprehension of foreign learners.

\subsection{Problem of the Study}

The main problem is Reading that it was considered a passive skill in some methods and approaches but with the communicative approaches, reading gained prominence and became an active and meaningful process rather than a passive product. The situation was worse when reading skill comes to proficiency learners' reading. Accordingly, proficiency learners have many problems in comprehending the texts. In proficiency courses, students are required to read texts, and translate them into first language, and answer comprehension questions. The problem with traditional approaches is that they do not consider reading as a purpose-driven.

Furthermore, the use of new methodologies in teaching English reading through courses is important. Therefore, this study will focus on reading and how approaches Task-Based Language Teaching can be influential and particularly useful in EFL reading improvement.

\subsection{Research Questions}

This research has four main research questions:

1). What are the mostly used teaching methods in developing reading comprehension at proficiency level of university students?

2). Is Task-Based Language Teaching method widely used at high level of university students?

3). Are there any similarities between Task-Based Language Teaching method and conventional teaching method on reading comprehension of proficiency level of university students?

4). Are there any significant differences between Task-Based Language Teaching method and conventional teaching method on reading comprehension of proficiency level of university students in implementing reading skills at pre-reading phase?

A. Are there any significant differences between Task-Based Language Teaching method and conventional teaching method on reading comprehension of proficiency level of university students in implementing reading skills on reading phase? 
B. Are there any significant differences between Task-Based Language Teaching method and conventional teaching method on reading comprehension of proficiency level of university students in implementing reading skills at post-reading phase?

\section{Methodology}

This study attempted to determine the effects of the Task-Based on the reading comprehension of foreign EFL learners. This study collected data from three instructors through observation checklist, interview questions will be used to three instructors. This study also used IELTS version test for task-based, for combination groups in to two groups of EFL learners. Both of the groups will be taught throughout 12 weeks, (two hours) a week for 12 weeks. The approach is learner-centered and interactive. The researcher used lesson plan based on two different methods. Learners trained in the use of strategies that needed to be effective on reading comprehension.

\subsection{Data Collection Instruments}

The current study was based on three main instruments. (1) Observation checklist for B2 classes, (2) interview questions for three instructors, and (3) two tests for two groups. The subjects of the study would be chosen randomly university students who attend high level of EFL classes. This study selected two groups at this center on the basis of random sampling. A proficiency test administrated at the center. Then these selected subjects were assigned to two groups and each group contains of learners, and their gender will vary. The subjects of this study were from different countries and they studied in different departments. There were both male and female subjects in each group

This study focused on one method and how they influenced on the reading comprehension at high level of EFL learners. The purpose was to achieve homogeneity between the two groups. The basis instrument was the task-based, and conventional tests on the subjects. Then after the treatment, again a version of a test were administered in order to find out the effectiveness of the one teaching method on the reading comprehension of foreign EFL learners.

\subsection{Participants}

The participants of the current study were chosen randomly from both two universities, Cyprus International University, and Akdeniz Kerbas students who are attended EFL classes in Fall-2017. The subjects of both two groups were 80 participants. The researcher selects two classes in EFL classes, each class has a limited number of students and it was more successful more than over crowded class room. Instructors were four subjects and they were expressed their knowledge seriously and correctly. In order to achieve homogeneity between two groups. IELTS test was administered and 80 of the subjects were chosen randomly. These learners were male, and female learners of classes based on sampling. The age range of participants was also controlled. All students were 20-27 years old. The pre- test contained the reading section of the IELTS - test and it contains 12 items. The reason for using pre- test IELTS is to make learners homogeneous regarding their reading abilities at the beginning of the study. Then after the treatment, again a version of IELTS test was administered in order to check the effectiveness of the Task-Based Teaching method on the reading comprehension of EFL learners.

\subsection{Data Collection Procedures}

This current study used the instrument through once a day for 12 weeks at English language 
center. Subjects who were study high level were chosen randomly among the learners at this center. In order to have two groups, a pre-test was administered. In fact the pre-test was a version of IELTS proficiency test. Then learners were chosen in each group and assigned in two groups based on random sampling. This way there were two groups. The reading skills was taught through Task-Based in group A. In group B, the subjects were control group conventional group. In the class, a reading program was taught based on TBLT and the class time was divided to three phases: pre-task, task cycle and post-task. In the pre-task phase the researcher attempted to activate the EFL learners' schemata related to the text and motivated them to read. In the during-task phase, the students were engaged in completing different kinds of tasks, and in the post-task phase, they given a report. Repeated the tasks and practiced of some formal and linguistic features of the text.

In the conventional class (group B) the syllabus was organized around themes or topics related to the specific subjects. The students read authentic materials and all the exercises were answered through grammar-translation method and class activities were designed around the reading text. There was no treatment for this group. The test was given to the participant pre-test and after 12 weeks the research given the same test for the control group. And after that a reading post-test was given to the control group to compare their improvement.

\subsection{Data Analysis Procedures}

Data collected and analyzed by t-test and SPSS in order to investigate if the teaching methods have any effect on EFL learners. The scores of pre-test and post-test tests compared by using t-test. Then an independent t-test used to check which of the methods has been more effective for teaching EFL learners.

\subsection{Hypothesis of the Study}

The researcher assumed the limitation of the students in EFL classes was more successful than overcrowded classroom. EFL instructors expressed their knowledge of methodology sincerely and correctly. The researcher used non- parametric statistical because of limited numbers.

The researcher used SPSS to measure Cronbach's alpha that we're required for a pilot test before the researcher used the instrument to continue with this research. The Cronbach's alpha was 0.875 and the numbers were 5 .

\subsection{Definitions of Key Terms}

\subsubsection{Task-Based Language Teaching (TBLT)}

Ellis (2003) argued that TBLT focuses on classroom processes that grammar and communicative competence can be developed by- engaging learners in interactive tasks. This method also focuses on cooperative learning which students are divided into groups to participate together. This technique is based on student achievement groups.

The teacher should be following suitable steps for EFL learners at advanced level:

1). Specifying clearly the objectives for the lesson;

2). Dividing students into small four groups for each learning team. Each team should be heterogeneous of ability and gender;

3). Introducing a new reading text. Students work freely in their groups to offer different answers to the problems, brain storming, and sharing ideas, so they realize that their goal is 
understanding. They are continuing to work until each group member feels he/she gets the concepts involved in the exercise, through questioning each other in pairs;

4). Evaluating the students' achievement and check for understanding, by testing, using task work for the individuals separately and for the team. Rewards are given on a team basis, based on team achievement;

5). Giving the team highest score, or the team's work is displayed on the bulletin board. (Ellis, 2005).

\subsubsection{English Reading Comprehension}

Brumfit (1999). assumed that reading comprehension is to process of negotiating understanding between the reader and the writer. It is a more complex psychological process and includes linguistic factors such as phonological, morphological, semantic, and syntactic elements, in addition to cognitive factor. The purpose of the reader is to receive information from the author via words, sentences, paragraphs, and try to understand the inner emotional of writer. Second language learners need to understand how to learn meaningful from texts by using higher level skills; relating what they read, what they know, they are understand the ideas, detailed information.

\subsubsection{Communicative Teaching Method}

This method is based on interaction between students in EFL classrooms. Although this method emphasizes on the meaning rather than form. Teachers are used three steps: presentation and practice and production for their lessons. The first step. Presentation, teachers exhibit new words from the text and explain to students. The second step. Practice, students learn how to repeat the new words after two times in the class groups and individually. Students read and complete the passage by themselves. Teachers ask them questions related to the passage, in this way students answer the questions orally. The third step. Production, students participate and engage in production by writing answers related to the text exercises. Rumelhart (1977).

\section{7 Limitations}

This study was limited as the following:

1). Age limit, the participants of the study will be a large age range of 25 to 40 .

2). Only one skill, in the reading comprehension of foreign learners who have been taught reading through TBLT.

\section{3). Approach limit, Task-Based Language Teaching (TBLT).}

4). Two Years limit, the participants were at proficiency level of proficiency.

5). Location limit, the participants of the study were restricted to language centers at Cyprus International University and Akdeniz Kerbas University.

\section{Results and Discussions}

It was clear and greater that Group one for experimental group has done better more than control group the second group. Students who take task-based program through 12 weeks were successfully learning reading comprehension, whereas control group didn't take any program only test were in low level. It has seen that task-based language teaching method was effective than communicative method in teaching reading comprehension to EFL 
learners at Cyprus universities. As it was observed in this study that pre-intermediate learners who have been taught reading comprehension through task-based language teaching (TBLT) effective more than control group who were taken test without learning activities through task-based method.

\section{Conclusion}

It was clear that TBLT is a very successful method in which teacher attempts to activate the learners background knowledge by ask learners to complete tasks. TBLT was a more effective, authentic, meaningful and purposeful in pre-reading phase. It was more elaborate and complete. TBLT approach, in contrast other methodologies for teaching reading comprehension is a very clear and simple use of varied activities such as photos, list of questions, table, figures. All of these are important advantages of TBLT that can be based on for justifying the out performance of TBLT group in contrast with another group who participants in communicative group.

\section{References}

Allen, J. P. B., \& Widdowson, H. G. (1974). Teaching the communicative use of English. Oxford: Oxford University Press.

Bowen, T. (2004). Task-Based Learning. Retrieved April 18th, 2008, from http://www.onestopenglish.com/section.asp?docid=146402

Brown, H. D. (2001). Teaching by principles: an introduction approach language pedagogy. (2nd Ed). New York: Pearson Education.

Brumfit, C. (1999). Communicative methodology in language teaching. Cambridge: Cambridge University Press.

Celce-Murcia, M. (2001). Teaching English as a second language. (3rd Ed). Boston: Heinle \&Heinle Publishers.

Ellis, R. (2000). Task-based research and language pedagogy. Language teaching research. Oxford: Oxford University Press.

Ellis, R. (2003). Task-based language learning and teaching. Oxford: Oxford University Press.

Ellis, R. (2005). Planning and task performance in a second language. Amsterdam: Benjamins. https://doi.org/10.1075/11lt.11

Eskey, D. (1990). Second language reading for the 90s. Journal of the language teacher, 14(9), 23-25.

Kintsch, W. (1988). The role of knowledge in discourse comprehension: A construction-Integration model. Psychological Review, 95, 163-182. https://doi.org/10.1037/0033-295X.95.2.163

Kintsch, W. (1998). Comprehension: A paradigm for cognition. New York: Cambridge University Press.

Rumelhart, D. E. (1977). Toward an integrative model of reading. In S. Dornic (Ed.), Attention and performance (pp. 573-603.). New York: Academy Press.

Rumelhart, D. E. (1984). Schemata and the cognitive system. In R. S. Wryer. Jr \& Tulk, The 


\section{Macrothink}

world of text. (pp. 76-98). New York: prentice Hall.

Sanford, A. J., \& Garrod, S. C. (1981). Understanding written language: Explorations of comprehension beyond the sentence. New York: Wiley

Schank, R. C., \& Abelson, R. (1977). Scripts, Plans, goal, and understanding. Hillside, NJ: Lawrence Erlbaum Associates.

Schnotz, W. (2002). Commentary - towards an integrated view of learning from text and visual displays. Educational Psychology Review, 14(1), 101-120. https://doi.org/10.1023/A:1013136727916

Shahnazari, M. T., \& Dabaghi, A. (2014).A critical overview of models of reading comprehension with a focus on cognitive aspects. Iranian Journal of Research in English Language Teaching, 1(3), 7-19.

Stanovich, K. (1980). Toward an interactive-compensatory model of individual differences in the development of reading fluency. Reading Research Quarterly, 16, 32-71. https://doi.org/10.2307/747348

Stanovich, K. E. (1986). Matthew effects in reading: Some consequence of individual differences in the acquisition of literacy. Reading Research Quarterly, 21(4), 360-407. Trabasso, T., \& Sperry, L.L (1985). Causal relatedness and importance of the strong events. Journal of memory and language, 24, 595-610.

Van den Broek, P., \& Gustafson, M. (1999). Comprehension and memory for texts. Three generations of reading research. Journal of Memory and Cognition, 29, 51-84.

Zewan, R. A., Langston, M. C., \& Grasser, A.C. (1995). The construction of situational models during comprehension. Journal of Memory and Language, 13, 441- 469.

\section{Copyright Disclaimer}

Copyright reserved by the author(s).

This article is an open-access article distributed under the terms and conditions of the Creative Commons Attribution license (http://creativecommons.org/licenses/by/3.0/). 